leksicheskie-markery-neopredelennosti-v-razgovornom-angloyazychnomdiskurse

4. Песина С. А., Пулеха И. Р., Калашник Д. М. Лингвокогнитивный подход к интерпретации категории неопределенности (на материале английского языка). URL: https://cyberleninka.ru /article/n /lingvokognitivnyy-podhod-k-interpretatsii-kategorii-neopredelennosti-na-materialeangliyskogo-yazyka

DOI https://doi.org/10.30525/978-9934-26-180-0-17

\title{
«ПРОСНИСЬ, САМУРАЙ!»: К ВОПРОСУ ОБ ОСОБЕННОСТЯХ УПОТРЕБЛЕНИЯ ЯПОНИЗМОВ В КИБЕРПАНК-ЛИТЕРАТУРЕ
}

\author{
Донец П. Н. \\ преподаватель кафедры романо-германской филологии \\ и методики преподавания иностранных языков \\ Международный гуманитарный университет \\ г. Одесса, Украина
}

Киберпанк сегодня у всех на устах. Некогда «похороненный» своими же создателями, жанр без преувеличения переживает свой второй Ренессанс: к нему вновь обращаются писатели-фантасты, кинорежиссёры, художники, музыканты, аниматоры и разработчики видеоигр, активно интегрирующие в свои произведения киберпанковскую эстетику. Об одном из аспектов этой эстетики мы сегодня и поговорим.

Те, кто хоть раз погружались в мрачные и неприветливые миры киберпанка, наверняка обратили внимание на характерную для жанра деталь - обилие в повествовании японских элементов. В данном случае речь идёт не о киберпанке японского происхождения (там-то как раз их наличие абсолютно оправдано и уместно), а о его заокеанском родоначальнике: как мы помним, жанр зародился в США в начале 80-х годов.

Увлечённость фантастов-восьмидесятников Страной восходящего солнца - феномен достаточно хорошо изученный. На вопрос, почему киберпанк настолько японский, и откуда в нём возникли самураи, дзайбацу и якудза, не раз отвечали и сами писатели, и многочисленные исследователи их творчества. Суммируя сказанное ими, отметим, что эти причины имеют, по крайней мере, три измерения: социально-экономическое, философское и культурное. 
Пока США переживали депрессию 70-80-х гг. в экономике и общественной жизни, Япония, наоборот, испытывала небывалый техникоэкономический подъём. Вчерашний «младший партнёр», казалось, вот-вот возьмёт исторический реванш за проигрыш во Второй мировой благодаря технологическому и коммерческому превосходству, пугающим новшествам вроде компьютеров и роботов, железной корпоративной дисциплине и красочной аниме-культуре. Вторжение японских компаний на американские рынки совпало с подогреваемыми телевангелистами эсхатологическими и милленаристскими настроениями по поводу наступления нового тысячелетия. Как и многие американцы начала 80-х, писатели-фантасты были одновременно напуганы и очарованы Японией, олицетворявшей собой наступающее будущее и казавшейся тогда кандидатом в новые мировые гегемоны.

Сконструировав в образе японцев экзотического Другого, американский сай-фай положил начало новому явлению - постмодернистской форме ориентализма с приставкой техно- или хай-тек $[4$, p. $11 ; 5$, p. 31]. Сложилась парадоксальная ситуация, когда классический киберпанк с первых лет своего существования был наполнен японскими мотивами даже больше, чем, собственно, его японский аналог.

Как мы знаем из истории, эти страхи оказались напрасными. Стремительный взлёт «азиатского тигра» обернулся катастрофическим крахом фондового рынка и всего «японского пузыря» в 1990-м году. Тем не менее, аллюзии на восточную культуру отнюдь не исчезли из киберпанковских произведений, скорее наоборот - они в них закрепились, став их неотъемлемым атрибутом. В пришедшем на смену посткиберпанке герои всё так же носят японские имена («Видоизменённый углерод» Р. Моргана), противостоят борёкудан и дзайбацу («Электрическая церковь» Дж. Сомерса) и решают конфликты взмахами катаны («Лавина» Н. Стивенсона).

Чем объясняется такая живучесть ориентального нарратива? На первый взгляд, ответ лежит на поверхности. Современный киберпанк использует проверенные временем техники и приёмы уже не как средство предупреждения или элемент нагнетания атмосферы, а как атрибут ностальгии, ретрофутуристический штрих, дань памяти классике. Такая трактовка будет отчасти верной, особенно в отношении таких коммерчески успешных проектов, как роман «Первому игроку приготовиться» Э. Клайна, кинотрилогия «Матрица» или ролевой экшен Cyberpunk 2077, где японские или шире - азиатские элементы - нередко выступают сознательным оммажем традиционному киберпанку.

Однако если копнуть глубже в стилистику жанра, роль японских заимствований окажется не столь однозначной. Как будет показано в нашем грядущем исследовании, японизм (не путать с одноимён70 
ным художественным направлением в западноевропейском искусстве XIX столетия) - неотъемлемый структурный компонент лексикосферы жанра, в разные времена выполнявший неодинаковые стилистические функции. В предстоящей статье мы детально изучим это явление и на примере нескольких знаковых произведений сравним, как и для чего использовались японизмы на различных этапах эволюции киберпанка. Пока же обозначим ряд ключевых тезисов.

1. Японизм - стилистическое средство, троп, имманентно присущий киберпанку с момента его возникновения. Японские заимствования несут в себе не только эстетическую, но и экспрессивную функцию. Будучи первоначально сугубо американским феноменом, транснациональные корпорации намеренно маркируются в произведениях У. Гибсона иноязычным термином дзайбацу. Согласно точке зрения $\mathrm{B.} \mathrm{Чун} \mathrm{из}$ Университета Саймона Фрейзера, таким способом писатель достигает эффекта дефамилиаризации читателя, разоблачая тем самым стереотип, будто корпоративная модель капитализма символизирует американское превосходство [1, p. 13].

2. Японизмы в киберпанке обладают рядом грамматических и лексикосемантических особенностей. В подавляющем своём большинстве они представлены двух- и трёхсложными моносемическими существительными. Полисемия присуща в основном лексемам, связанным с воинским делом и боевыми искусствами (например, самурай, ниндзя, сенсей, ронин), что также, по-видимому, не случайно. Киберпанки были очарованы неповторимой иконографией и традиционной боевой культурой Японии, подчёркивает профессор Американского университета в Вашингтоне Э. Дассер [2, p. 268].

3. Большинство японизмов представлены широко употребимыми, доступными неподготовленному читателю лексемами, не требующими дополнительного перевода или сносок (например, кимоно, суши, гейша). С одной стороны, это свидетельствует о стереотипном восприятии западными фантастами Японии, с другой - о всепроникающем и глобальном свойстве её массовой культуры.

4. На разных этапах развития киберпанка роль японизмов изменяется в соответствии с господствующим на Западе «духом времени». Если в произведениях 80-х их функция была в основном алармистской и отчуждающей, то в 90-х - это уже элемент деконструкции жанра. Профессор Университета Пейс в Нью-Йорке Т. Хенторн обращает внимание, что в дебютной трилогии Гибсона «Киберпространство» ориентализм подаётся через бинарные оппозиции, где американский индивидуализм в лице хакера Кейса противопоставлен «бездушному» восточному корпоративизму в собирательном образе дзайбацу. Однако уже во второй трилогии «Моста», после того как японская экономика 
пережила коллапс, восприятие Гибсоном этой страны меняется: она всё ещё экзотифицируется, но уже не воспринимается антагонистично, несмотря на то, что Япония, согласно сеттингу, всё ещё превосходит США технологически [3, p. 75]. Наконец, в 2010-х годах на фоне нового всплеска интереса к киберпанку, японизмы возвращаются, но уже в качестве игры с жанровыми клише.

5. Японизмы в киберпанке можно условно разделить на две категории: хай-тековые и лоу-тековые соответственно. Первая группа представлена в основном стилистически нейтральной ономастической лексикой: сюда можно причислить названия корпораций, имена действующих персонажей, а также многочисленные топонимы и урбанонимы. Отдельный интерес представляет собой вторая группа, в которую мы отнесли заимствования, репрезентирующие объекты Древней Японии. По меткому наблюдению профессора Мичиганского университета Л. Накамуры, если фантастика «золотого века» облачалась в греко-римские тоги, то киберпанковская проза инкорпорировала в себя японское феодальное прошлое: хай-тековый футуризм удивительным образом сосуществует в ней с анахронизмами периода Эдо и Мэйдзи (отсюда всевозможные ниндзя и самураи) [1, p. 12]. Как можно догадаться, выбор именно этих двух эпох также неслучаен и обусловлен историческими особенностями обеих, что будет подробно рассмотрено в последующей статье.

В завершение отметим, что японизация американского киберпанка происходила параллельно с американизацией киберпанка японского - это два неразрывных процесса, протекавших, по сути, одновременно, и поэтому их не следует рассматривать отдельно друг от друга.

\section{Литература:}

1. Chun W. H. K. Orienting Orientalism, or How to Map Cyberspace. Asian America.Net: Ethnicity, Nationalism, and Cyberspace. New York : Routledge, 2003. pp. 3-36.

2. Dussere E. America Is Elsewhere: The Noir Tradition in the Age of Consumer Culture. Oxford : Oxford University Press, 2014. 320 p.

3. Henthorne T. William Gibson: A Literary Companion. Jefferson : McFarland, 2011. $176 \mathrm{p}$.

4. Park J. C. H. Yellow Future: Oriental Style in Hollywood Cinema. Minneapolis : University of Minnesota Press, 2010. 272 p.

5. Sanders L. P. Postmodern Orientalism: William Gibson, Cyberpunk and Japan. Albany : Massey University, 2008. 300 p. 